\title{
A Simple Question with a Multivariate Answer
}

\author{
Fausto Feres ${ }^{1}$, Ivana Carneiro Feres ${ }^{2}$, Roberto Vieira Botelho ${ }^{3}$
}

D iscussion of the cost-effectiveness analysis of drugeluting stents (DES) is both extremely important and necessary, although challenging. Perhaps this urgency contradicts what research has recently demonstrated regarding such devices: the obvious clinical benefit of DES in all analysed subgroups in randomised experimental scenarios and in real patients. ${ }^{1,2}$ This year marked the tenth anniversary of the use of this groundbreaking technology in our field. Several studies have shown both the efficacy and safety of these devices for coronary restenosis reduction compared with bare-metal stents (BMS). ${ }^{3-5}$ Data favouring their use have led to increased deployment. Cardiologists must consider the novelty and high cost of this technology; conversely, they must consider the undeniable benefits it provides. The question must be asked: is this treatment cost-effective?

\section{See page 21}

In the study published in this issue of the Revista Brasileira de Cardiologia Invasiva, Ferreira et al. ${ }^{6}$ compared the performance of the Taxus ${ }^{\circledR}$ DES and the Liberté ${ }^{\circledast}$ BMS in consecutive, non-randomised patients. Even in countries where the DES/BMS relationship is not as heavily promoted as in this sample, and despite the reduction of restenosis with DES in all subgroups analysed, the development of a model of maximal benefits is necessary. In one of these recently published models, ${ }^{7}$ the number needed to treat (NNT) with DES to avoid new revascularisation of the target vessel ranged from 6 to 80. This finding means that in certain subgroups, restenosis with BMS was so low that it would be necessary to treat 80 patients with DES in order to avoid a new procedure. Conversely, in other subgroups, restenosis with BMS was high, and the NNT with DES to avoid a new procedure was only 6 . These concepts generate a proper discussion regarding the moment at which a decision must be made, and the clinician must compare the clinical benefit of using a device versus public health policies in order to optimize the incorporation of new technologies.

The cost-effectiveness concept can be defined as the difference between the cost of the two interventions, expressed in monetary value, divided by the difference between their effectiveness, expressed in years of life gained (life expectancy) or in order less important outcomes, such as the number of prevented complications and the number of averted non-fatal events. ${ }^{8}$ Regarding BMS, the following question must be asked: what is the additional cost for each new averted revascularisation? In Brazil, the values obtained in order to avoid either a new revascularisation or an event in the target vessel were $R \$ 47,000$ in the analysis by Polanczyk et al., ${ }^{9}$ $R \$ 131,000$ in the analysis by Ferreira et et al., ${ }^{10}$ and the incredible value of $R \$ 190,000$ was obtained in the study by Quadros et al. ${ }^{11}$ Two variables influence these large figures, which are substantially higher than the US $\$ 1,650$ was found in the North-American study by Cohen et al. ${ }^{12}$ These variables are the following: the low incidence of clinical restenosis with BMS, which is exactly what we have seen in a study published in this issue (consequently, a higher number of patients need to be treated with DES to avoid restenosis); and the high prices of both stents in addition to the high DES/BMS cost ratio, which is always greater than 3, or in absolute terms, with a price difference between the two of greater than $\mathrm{R} \$ 8,000$.

In Ferreira et al., ${ }^{6}$ we observe that the comparison was based on high figures, either that of DES (approximately $R \$ 11,000$ ) or of BMS (approximately $R \$ 4,000$ - extremely expensive!). Despite the cost relationship between the two treatments, this has not been commonly observed by us.

A less relevant aspect of the proposed analysis, albeit considerable given the vision of utilising the best technology available, was the deployment of the Taxus $^{\circledR}$ paclitaxel-elutant stent. This is a first-generation

\footnotetext{
1 Instituto Dante Pazzanese de Cardiologia - São Paulo, SP, Brazil

${ }^{2}$ Complexo Hospitalar Edmundo Vasconcelos - São Paulo, SP, Brazil.

3 Instituto do Coração do Triângulo - Uberlândia, MG, Brazil.

Correspondence to: Fausto Feres. Av. Dr. Dante Pazzanese, 500 - Ibirapuera - São Paulo, SP, Brazil - CEP 04012-180

E-mail: fferes@lee.dante.br

Received on: 3/19/2012 • Accepted on: 3/20/2012
} 
DES that has yielded inferior results compared to those of the second-generation stents. ${ }^{13}$

Ferreira et al. ${ }^{6}$ used an observational, non-randomised, consecutive design, whose results were not monitored or even adjudicated by an independent external committee. Data are analysed under such considerations.

In an observational, non-randomised study, variables evaluated before performing an intervention that is under analysis and non-modifiable or non-affected variables are called covariants.

The propensity score ${ }^{14}$ is a method that seeks to balance these covariants to provide independence to the analysed variable. In other words, this method evaluates the impact selection bias over the effect of the treatment. This tool is applied in the beginning of the analysis, and has an effect similar to that of multivariate analysis deployed by regression, moving backwards from the events to its determinants.

This score subsequently provides a 'randomisation' effect for the known variables. It is limited by the unknown covariants, which are not included in the analysis. Its use does not preclude the specification of the suggested analyses or the sample calculation regarding the power and precision of the tool.

That study proposes a comparison of the two interventions that cannot be randomised due to ethical issues. Therefore, covariant control tools, such as propensity score, are useful.

The results presented so far qualify only as hypothesis generators due to the weakness imposed by the selection bias.

The authors comment about this limitation, which is inherent to the propensity score.

It must also noted that, even within this environment, sample calculation is fundamental to establish sample power and precision. That is, in considering the balancing capacity of the propensity score, does the sample size allow for the denial of null hypothesis?

Therefore, in this issue, more information is provided to the literature to judge a complex theme. Its interpretation deserves consideration regarding the study design, the selection bias attenuation method the DES type used, and the cost relationship between the two types of stents, before absolute conclusions can be reached.

\section{CONFLICTS OF INTEREST}

The authors declare no conflicts of interest.

\section{REFERENCES}

1. Kirtane AJ, Gupta A, lyengar S, Moses JW, Leon MB, Applegate R, et al. Safety and efficacy of drug-eluting and bare metal stents: comprehensive meta-analysis of randomized trials and observational studies. Circulation. 2009;119(25):3198-206.

2. Sousa A, Costa JR Jr, Moreira AC, Cano M, Maldonado G, Costa RA, et al. Long-term clinical outcomes of the DrugEluting Stents in the Real World (DESIRE) Registry. J Interv Cardiol. 2008;21(4):307-14.

3. Moses JW, Leon MB, Popma JJ, Fitzgerald PJ, Holmes DR, O'Shaughnessy C, et al. Sirolimus-eluting stents versus standard stents in patients with stenosis in a native coronary artery. $\mathrm{N}$ Engl J Med. 2003;349(14):1315-23.

4. Stone GW, Ellis SG, Cox DA, Hermiller J, O'Shaughnessy C, Mann JT, et al. A polymer-based, paclitaxel-eluting stent in patients with coronary artery disease. $N$ Engl J Med. 2004;350(3):221-31.

5. Venkitachalam L, Lei Y, Stolker JM, Mahoney EM, Amin AP, Lindsey JB, et al. Clinical and economic outcomes of liberal versus selective drug-eluting stent use: insights from temporal analysis of the multicenter Evaluation of Drug Eluting Stents and Ischemic Events (EVENT) Registry. Circulation. 2011;124(9):1028-37.

6. Ferreira E, Araújo DV, Azevedo VMP, Ferreira Jr A, Junqueira CLC, Amorim B, et al. Uso do escore de propensão na análise de custo-efetividade com utilização seletiva de stents farmacológicos e não-farmacológicos. Rev Bras Cardiol Invasiva. 2012;20(1):21-8.

7. Yeh RW, Normand SL, Wolf RE, Jones PG, Ho KK, Cohen DJ, et al. Predicting the restenosis benefit of drug-eluting stents versus bare metal stents in percutaneous coronary intervention. Circulation. 2011;124(14):1557-64.

8. Rassi A Jr. Economic analysis of drug-eluting coronary stents in Brazil: a choice for all or just for a few patients? Arq Bras Cardiol. 2007;88(4):376-7.

9. Polanczyk CA, Wainstein MV, Ribeiro JP. Cost-effectiveness of sirolimus-eluting stents in percutaneous coronary interventions in Brazil. Arq Bras Cardiol. 2007;88(4):464-74.

10. Ferreira E, Araujo DV, Azevedo VM, Rodrigues CV, Ferreira A Jr, Junqueira $C L$, et al. Analysis of the cost-effectiveness of drugeluting and bare-metal stents in coronary disease. Arq Bras Cardiol. 2010;94(3):286-92,306-12.

11. Quadros AS, Gottschall CAM, Sarmento-Leite R. Custo-efetividade dos stents revestidos com drogas em vasos de grande calibre. Rev Bras Cardiol Invasiva. 2006;14(3):306-13.

12. Cohen DJ, Bakhai A, Shi C, Githiora L, Lavelle T, Berezin RH et al. Cost-effectiveness of sirolimus-eluting stents for treatment of complex coronary stenoses: results from the SirolimusEluting Balloon Expandable Stent in the Treatment of Patients With De Novo Native Coronary Artery Lesions (SIRIUS) trial. Circulation. 2004;110(5):508-14.

13. Stone GW, Rizvi A, Sudhir K, Newman W, Applegate RJ, Cannon LA, et al.; SPIRIT IV Investigators. Randomized comparison of everolimus- and paclitaxel-eluting stents. 2-year follow-up from the SPIRIT (Clinical Evaluation of the XIENCE V Everolimus Eluting Coronary Stent System) IV trial. J Am Coll Cardiol. 2011;58(1):19-25.

14. Joffe MM. Invited commentary: propensity scores. Am J Epidemiol. 1999;150(4):327-33. 